\title{
New learning design in distance education: The impact on student perception and motivation
}

Citation for published version (APA):

Martens, R., Bastiaens, T., \& Kirschner, P. A. (2007). New learning design in distance education: The impact on student perception and motivation. Distance Education, 28(1), 81-93.

https://doi.org/10.1080/01587910701305327

DOI:

$10.1080 / 01587910701305327$

Document status and date:

Published: 25/05/2007

Document Version:

Peer reviewed version

Please check the document version of this publication:

- A submitted manuscript is the version of the article upon submission and before peer-review. There can be important differences between the submitted version and the official published version of record. People interested in the research are advised to contact the author for the final version of the publication, or visit the DOI to the publisher's website.

- The final author version and the galley proof are versions of the publication after peer review.

- The final published version features the final layout of the paper including the volume, issue and page numbers.

Link to publication

\section{General rights}

Copyright and moral rights for the publications made accessible in the public portal are retained by the authors and/or other copyright owners and it is a condition of accessing publications that users recognise and abide by the legal requirements associated with these rights.

- Users may download and print one copy of any publication from the public portal for the purpose of private study or research.

- You may not further distribute the material or use it for any profit-making activity or commercial gain

- You may freely distribute the URL identifying the publication in the public portal.

If the publication is distributed under the terms of Article 25fa of the Dutch Copyright Act, indicated by the "Taverne" license above, please follow below link for the End User Agreement:

https://www.ou.nl/taverne-agreement

Take down policy

If you believe that this document breaches copyright please contact us at:

pure-support@ou.nl

providing details and we will investigate your claim.

Downloaded from https://research.ou.nl/ on date: 26 Apr. 2023 


\title{
New Learning Design in Distance Education: The impact on student perception and motivation
}

\author{
Rob Martens ${ }^{a, b}$, Theo Bastiaens ${ }^{b, c}$ and Paul A. Kirschner ${ }^{b, d}$ \\ ${ }^{\mathrm{a}}$ Leiden University, the Netherlands; ${ }^{\mathrm{b}}$ Open University of the Netherlands; ${ }^{\mathrm{c}}$ Open \\ University of Germany (FernUniversität Hagen); ${ }^{\mathrm{d}}$ Utrecht University, the Netherlands
}

\begin{abstract}
Many forms of e-learning (such as online courses with authentic tasks and computer-supported collaborative learning) have become important in distance education. Very often, such e-learning courses or tasks are set up following constructivist design principles. Often, this leads to learning environments with authentic problems in ill-structured tasks that are supposed to motivate students. However, constructivist design principles are difficult to implement because developers must be able to predict how students perceive the tasks and whether the tasks motivate the students. The research in this article queries some of the assumed effects. It presents a study that provides increased insight into the actual perception of electronic authentic learning tasks. The main questions are how students learn in such e-learning environments with "virtual" reality and authentic problems and how they perceive them. To answer these questions, in two e-learning programs developed at the Open University of the Netherlands (OUNL) designers' expectations were contrasted with student perceptions. The results show a gap between the two, for students experience much less authenticity than developers assume.
\end{abstract}

\section{Introduction}

Developments in technology in the past decade have had considerable impact on the distribution of content, learning tasks, and assignments in training and distance education (Howland \& Moore, 2002). A rapid fall in prices and a huge leap in the processing capacity of PCs and the proliferation of the World Wide Web have unleashed new opportunities for useful educational applications (Martens, 1998).

Along with this "revolution" has come a new view on learning. Some authors use the term "new learning" (Simons, van der Linden, \& Duffy, 2000) when they refer

\footnotetext{
*Corresponding author. Center for the Study of Education and Instruction, Leiden University, PO Box 9555, 2300 RB Leiden, the Netherlands. Tel: +31 (0)71 5273394; Email: rmartens@fsw.leidenuniv.nl
} 
to the joint influence of constructivism and information and communications technology (ICT) on learning. Collaborative working and learning, development of higher order skills, self-assessment, coaching, authentic tasks as point of departure for learning, individual responsibilities, independent learning, and use of e-learning are keywords in this field. In Europe quite often such curriculum innovations are presented as "competency-based education." The Open University of the Netherlands (OUNL), for instance, has set an explicit goal of making all its programs and courses competency based. Almost always these new learning environments are based on constructivism. In the rest of this article we call e-learning tasks or courses for distance learning founded on constructivist principles "constructivist e-learning environments" (CEEs). CEEs (for instance, WebQuests, online courses, courses with simulations via the computer, virtual companies, management games and simulations) are used all over the Western world.

What does it mean to develop CEEs following constructivist principles? In this introduction we try to identify the basic characteristics of these principles and then take a look at the problems that educational developers of CEEs may have with the application of such principles.

Constructivism is not an approach to or a model for instructional design, but rather a philosophy of learning based on the idea that knowledge is constructed by the learner through activity. This philosophy underlies the development of instructional models that have much in common (for example, Bastiaens \& Martens, 2000; Dalgarno, 1998; Herrington \& Oliver, 2000; Pierce \& Jones, 1998). Dalgarno applied constructivism to a 10-point design model, which is depicted in Table 1.

Looking more closely at these principles the acid test for designers is to construct CEEs in such a way that they are challenging (but not too difficult) and placed in a realistic, authentic context, so that learners become intrinsically motivated (principle 10) to explore and control their own learning process. An example of such a CEE is a virtual company in which students role-play and collaborate via computer on ill-structured tasks (Bitter, Sloep, \& Jansen, 2003). In such a challenging and realistic context, authentic problems are presented and students are motivated to become active learners and collaborate. Indeed, the term "motivation" appears to be at the heart of the matter in constructivist learning. Ryan and Deci (2000) distinguish between extrinsic motivation, which refers to the performance of an activity in order to attain some separable outcome, and intrinsic motivation, which refers to doing an activity for the inherent satisfaction of the activity itself. The effort or motivation on which CEEs rely is intrinsic motivation, with its associated features, such as curiosity, deep-level learning, explorative behavior, and self-regulation (Ryan \& Deci, 2000). Simons et al. (2000) give three 6-step instructional models for guided learning, experiential learning, and action learning. These three models are specific examples of the new learning approach. In the first model, there is the phase "awaken students' curiosity" (p. 10), the second model displays the phase "let students follow their own curiosity and interest" (p. 11), and in the third model, we see the phase "organize action in such a way that curiosity arises from it" (p. 12). This again indicates that (intrinsic) motivation is 
Table 1. Constructivist educational design principles

\section{-1- Learner control over content and sequence}

The learners have some control over what they attempt to learn and when, to maximize the chance that they will be able to relate new knowledge to prior experience.

\section{-3- Top-down organization}

Where content is provided to learners, it should be sequenced in a top-down fashion, providing an overall picture before specific facts and skills are learned.

\section{-5- Discovery}

Learners should undertake activities that allow them to put new skills into practice in realistic contexts.

\section{-7- Authentic activity}

The learners should undertake activities that allow them to put new understandings and new skills into practice in realistic contexts.

\section{-9- Metacognitive strategies}

The process that the learners use to discover information and principles should be valued and the learners should be encouraged to monitor their own learning and to use appropriate metacognitive strategies.

\section{-2- Learner control over learning strategy}

The learner should have some say in the methods of teaching and learning employed, as different learners will construct their knowledge in different ways.

\section{-4- Content in context}

Where content is provided to learners, it should be provided within a context, and to assist with generalization and transfer to other situations, multiple contexts should be provided.

\section{-6- Zone of proximal development}

The learners should undertake activities that are currently just beyond their ability, but with assistance provided to enable them to successfully complete activities.

\section{-8- Articulation and discussion}

The learners should undertake activities that require them to articulate their knowledge representations and to discuss their understanding of ideas with other learners as this will help them to develop their knowledge.

\section{-10- Intrinsic motivation}

The learners will only learn if they are motivated in such a way as to allow them to apply their attention to the piecing together of the concepts to be learned. Ideally this motivation should be intrinsic to the tasks learners carry out.

Adapted from Dalgarno (1998).

seen as crucial in constructivist learning (compare with Gagné, Briggs, \& Wager, 1992). Intrinsically motivated students do not necessarily put more effort in their learning or spend more time on it, but their effort is qualitatively different. Research has shown that intrinsically motivated students display more behavior that can be described as explorative, self-regulated, and aimed at deep-level processing, exploration, and reflection (for example, Boekaerts \& Minnaert, in press; Ryan \& Deci, 2000). It is important to note that the learners' perception is crucial. The question is not if a task is authentic, interesting, or challenging, but whether it is perceived as such by students.

\section{The Developers' Challenge}

What is it like for educational developers to design such tasks? Evidence from research indicates that it appears to be difficult and that applying the abovementioned design principles is by no means a guarantee for success. 
First, it is very hard to determine what competencies or "new learning skills" are. This problem of definition all too often causes confusion among the many stakeholders, such as teachers and educational developers (Kessels, 1999; Stoof, Martens, van Merriënboer, \& Bastiaens, 2002). Often, it is not recognized in good time and because of that it is underestimated.

Second, the development and implementation of this "new learning" is not easy because it is a combination of a new educational paradigm, new educational technology, and often an electronic learning environment. When we look at ICT tools for educational developers, we see a strong emphasis on delivery and much less on systematic design or evaluation. Thus, what is delivered to students is driven strongly by what is technologically possible rather than what is educationally desirable. Developers tend to focus on the phases of development and implementation and much less on analysis and evaluation (van Merriënboer \& Martens, 2002).

Third, designers have to gauge how students will perceive the tasks. In independent learning situations, once the tasks have been delivered to the students, there is relatively little control over student perception (Martens, 1998).

Fourth, there is a paucity of clear guidelines for designing new learning tasks (Brush, 1998; Martens, Jochems, \& Kirschner, 2002; Veerman, 2000) and assessment tasks for them (Sluijsmans, 2002). Guidelines, such as those in Table 1, leave much to the developers' creativity, intuition, and insight; this is also the case with specific ICT elements, such as computer-supported collaborative learning (CSCL). Despite its popularity, there are no clear guidelines for CSCL design (for example, Kaatinen \& Kumpulainen, 2002).

Fifth, very little solid empirical research has been reported on the supposed motivational impact of "constructivist" e-learning programs. Further, claims have rarely been grounded on empirical evidence (Reiser, 2001; Song \& Keller, 2001; Wolters, 1998).

Finally, there is little insight into the effects of new learning programs. Research is often conducted in non-ecologically valid settings (Driscoll, Moallem, Dick, \& Kirby, 1994; Naidu \& Bernard, 1992). Systematic objective evaluation is neglected in innovation in education, training, and human resource development (Dillenbourg, Eurlings, \& Hakkarainen, 2001), and often it is aimed more at output and less on student perceptions and behavior (Naidu \& Bernard, 1992). For instance, looking at key concepts such as motivation, researchers at large conferences such as the European Association for Research on Learning and Instruction (EARLI) may refer to motivational processes, but rarely underpin their claims with data (for example, EARLI, 2001).

In general, evidence suggests that high expectations are often not fulfilled. With independent learning, research findings indicate a gap between the assumptions of the developers (of the learning initiative, software, or training) and student opinions, and the way the material is used and its effectiveness (Gros, 2001). For example, Vermetten, Vermunt, and Lodewijks (2002) show that students do not learn differently in CEEs, although it was expected that they would. They state that, "the reform mainly failed to influence reported learning strategies in the direction of more 
deep and self-regulated learning" (p. 263). The more emphasis is put on independent and individual learning, the less insight developers have on what students actually do. Research in more traditional education yields evidence that students' opinions about the importance of certain parts of the course material differ from those of their teachers (Broekkamp, van Hout-Wolters, Rijlaarsdam, \& van den Bergh, 2002). Other researchers in the field of distance learning find that self-study methods often lead to unpredictable study outcomes (Martens, Valcke, Poelmans, \& Daal, 1996; Martens, Valcke, Portier, Weges, \& Poelmans, 1997).

It can be concluded that many "new learning" CEEs are presented to students with a high degree of technological optimism, using the state-of-the-art technology, but with considerable less attention on the instructional design and didactics. This "technological dazzle" masks the fact that design guidelines are vague and that designers might well hold misconceptions about how students experience these new learning environments. Moreover, it conceals whether, for example, the CEEs really make students more intrinsically motivated. Constructivist learning principles put emphasis on student perception and motivation. However, in a distance education context, there are reasons to believe that it is generally difficult for designers to predict how students perceive CEEs. Nevertheless, there are many claims of positive results obtained with such new CEEs. This study investigates the difficulty faced by developers in making accurate predictions about student perceptions.

Consequently, the main research questions are: How do students learn in CEEs that provide a "virtual" reality and authentic problems? How do they perceive it? How do these student opinions relate to the opinions and expectations of developers? Thus, this study foregrounds student perceptions of various aspects of CEEs. In line with the introduction, it deals with variables about how students perceive the illstructuredness of authentic problems and tasks, and the roles they have to play in these innovative programs; the perceived support from the e-learning environment and the support from the coach; intrinsic motivation and extent of explorative behavior. The research measured perceptions of the amount of collaboration with other students, and opinions about the usefulness of discussions with other students in programs that involve computer-supported collaboration. It was conducted in an ecologically valid context, dealing with participants who actually study for grades and who paid for the courses. Students' actual perceptions were contrasted with the developers' expectations.

\section{Method}

\section{Participants}

In this project the focus was on the expectations and experiences of students $(n=$ 61) compared with the assumptions of the developers $(n=5)$ of two OUNL CEEs (courses). All students were OUNL students, with an even distribution of men and women, and an average age of 30 . They were all studying or had recently studied OUNL certificate courses. 


\section{Materials}

The participants were studying or had recently finished studying the CEEs Learning to plead $(n=17)$ or Act in a session of the court $(n=48)$ (designed by Wöretshofer \& Nadolski, 1998). The two CEEs have been developed as a substitute for a period of practical training, which is difficult to organize for distance students. Students had to work individually and/or together via the computer on "real cases" in roles such as a counselor or lawyer. Both CEEs are set up following constructivist design principles (for example, Dalgarno, 1998). The first CEE involves CSCL; the second does not. Both have an estimated study load of 4 weeks and both present authentic tasks in which students have to assume the role of a lawyer, for instance.

The students had to respond to closed questionnaire items on 11 scales, measuring various aspects of their perception of the CEEs, such as the extent to which the CEEs stimulate exploration. All items were rated on a five-point Likert scale. Table 2 presents the subjects and the reliability of the scales. There is one scale with a reliability below 0.65 , meaning that the results from that scale have to be treated with caution. The items, translated from Dutch, are presented in the Appendix. The response rates were about $40 \%$, which can be considered high for this type of research with participation on a voluntary basis.

\section{Procedure}

Students received questionnaires by post and were asked to return them anonymously in a prepaid envelope. The developers were interviewed and received the same printed questionnaire. They were not given access to the student scores.

\section{Method of Analysis}

The scores of the subjects were compared with standard scores, based on the developers' opinions. The standard score was determined via structured interviews with

Table 2. Reliability of the scales on perception of the CEE

\begin{tabular}{lcc}
\hline Dependent variables & Items & Alpha \\
\hline Perceived authenticity of the e-learning environment & 4 & 0.84 \\
Extent of confusion regarding the e-learning environment & 4 & 0.72 \\
Experienced support in the e-learning environment & 3 & 0.78 \\
Extent of explorative behavior of the learner & 3 & 0.91 \\
Extent of collaboration with other learners & 3 & 0.94 \\
Opinion about usefulness of discussion with other learners & 3 & 0.80 \\
Positive opinion about the use of role-play & 3 & 0.60 \\
Positive opinion about the coach/facilitator & 3 & 0.86 \\
The e-learning environment urges exploration & 3 & 0.88 \\
The e-learning is innovative & 3 & 0.68 \\
Intrinsic motivation & 5 & 0.85 \\
\hline
\end{tabular}


the developers and by asking the developers to fill in the student questionnaires as if they were students; in other words, developers were asked to estimate the average student score for their specific CEE. Thus, a norm score was calculated per course, for comparison with student scores via one sample $t$-test. Factor analysis was used to test for the interdependence of the scales, in order to avoid multiple testing effects.

\section{Results}

Table 3 shows the results of the student and developer opinions on the two elearning environments. The table shows quite significant differences between the opinions of the students and those of the developers. The most notable findings are highlighted here. We compared the developers' scores with the students' scores. First, looking closely at the e-learning environment where students learn to plead, it is noticeable that the students' score on extent of explorative behavior is lower than that expected by the developers: it was expected that the authentic context of the CEE would stimulate explorative behavior. Students also had less positive opinions about the coach/facilitator. The students in the second CEE (where students act in a court session) scored especially low on perceived authenticity. It was surprising that students in both CEEs scored lower than the developers on their opinions about the use of the role-play. It was expected that working in the authentic role as lawyers would be stimulating for the students. On the other hand, for both CEEs, the score on extent of confusion was lower than expected, although the developers assumed that e-learning environments presented ill-structured problems.

Finally, we can also look at the students' scores apart from the comparison with the designers' scores. From these absolute scores it can be concluded that students are generally positive about the CEE.

Table 3 presents the results on the scales separately for comparison. Since our aim is to find all different possible sources of disagreement between developers' and students' opinions (decreasing the chance of a Type II error) a normal Bonferroni correction for multiple testing would be too conservative. To avoid unwanted multiple testing effects (Type I error) we analyzed the correlation matrix for all the subjects, followed by a factor analysis, which shows that individual variations are high enough; in most cases there is no overlap with other scales. But the intercorrelation of three scales ("Extent of explorative behavior of the learner," "The e-learning environment urges exploration," and "Intrinsic motivation") was higher than 70 . The result on a principal components analysis on a common factor is 2.58 for the eigenvalue, $86 \%$ declared variance. To prevent a Type I error caused by multiple testing, a new comparison was conducted using this factor, interpreted as "show explorative behavior related to intrinsic motivation," after calculating the $z$-value. The new comparison shows no significant difference for Learning to plead with standard (developers') score (0.55) and student scores $(M=0.06, S D=0.78)$. For Act in a session of the court there is indeed a significant difference (standard score $=-$ 0.53 , student score $=-0.37(S D=1.1) ; t=2.97 ; p<0.05)$. 


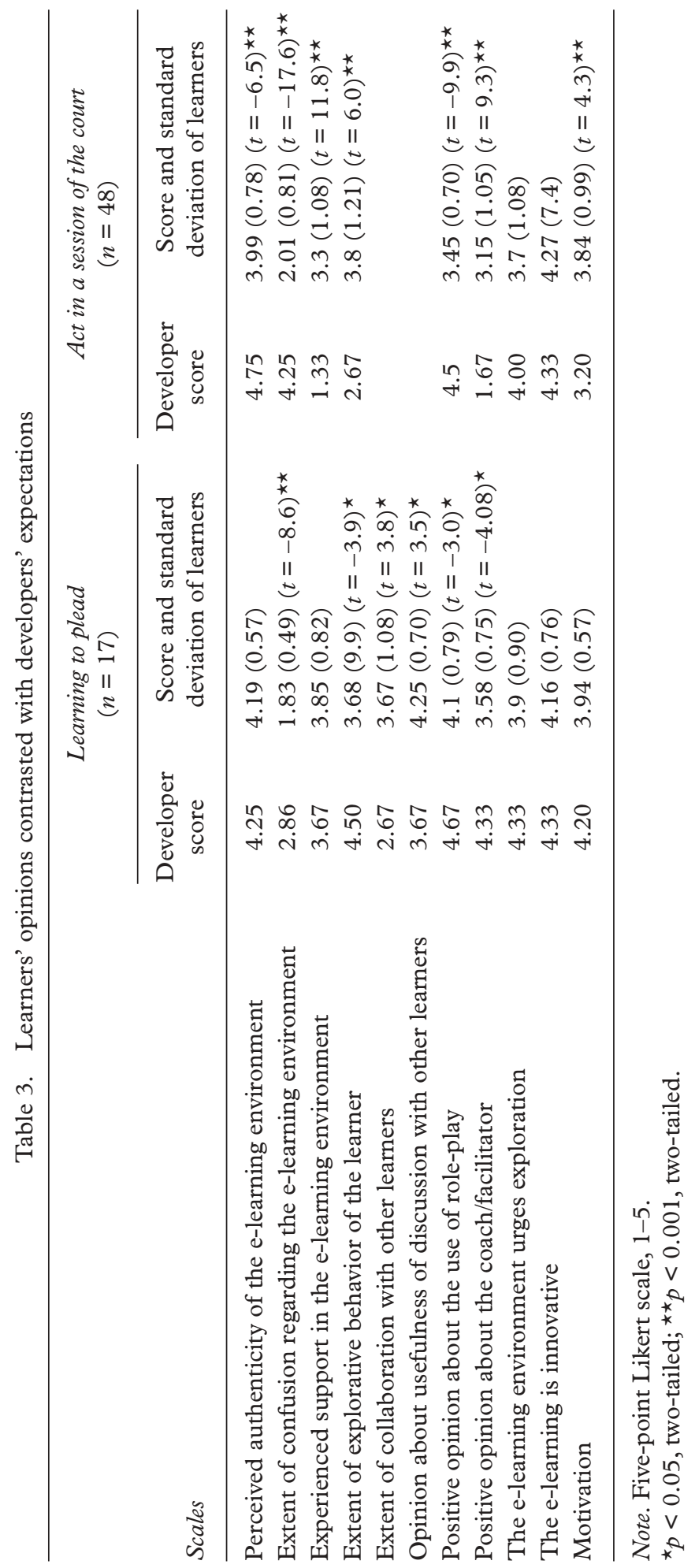




\section{Discussion and Conclusions}

The central issue in this study was whether the high hopes and expectations (Simons et al., 2000), although often implicit or not well founded (Stoof et al., 2002), of CEEs, are in line with the student perceptions of these environments. Based on earlier research, it is assumed that students do not behave as expected by developers in (individual) learning environments (Broekkamp et al., 2002; Martens et al., 1996; Naidu \& Bernard, 1992; Vermetten et al., 2002). The development process of authentic CEEs is often focused on its technical possibilities and state-of-the-art delivery and less on its systematic design and evaluation (Dillenbourg et al., 2001; van Merriënboer \& Martens, 2002). Although some research is available on the impact of new learning environments on student perception (for example, Howland \& Moore, 2002) and student motivation (for example, Song \& Keller, 2001), there is a need for empirical evidence.

The research reported in this article was carried out in the context of the OUNL, a university for distance learning. Two CEEs had been developed as a substitute for practical training. Students in these environments had to work individually and/or together via the computer on "real cases" in roles such as a counselor or lawyer. The expectations of the developers were compared with the experiences of the students. These expectations often did not match the reality. Developers had tried to develop tasks following constructivist design principles (for example, Dalgarno, 1998): ill-structured tasks designed to stimulate students to become intrinsically motivated to resolve the "confusion" and hence construct the required knowledge and skills. But the students did not think that the CEEs were particularly confusing. Moreover, the score on perceived authenticity was lower than expected. This illustrates how difficult it is for developers to estimate student perception of such crucial concepts, and that guidelines for doing so appear to be too vague.

The students did not appreciate role-playing as much as the developers had expected.

Before drawing final conclusions, some critical remarks about the study reported here have to be made. First, the scale "positive opinion about the use of role-play" had a reliability of only 0.60 , which is considered moderate, so conclusions related to this scale have to be treated with caution. Second, this study relied on selfreported perceptions only. A follow-up step would be to further explore actual student behavior in e-learning programs, related to key variables such as intrinsic motivation. Howland and Moore (2002), for instance, found a relationship between positive student attitudes towards their online course and their behavior as constructivist learners. Third, the participants in this study did not include those students who dropped out prior to this research. Those early dropouts might have been relatively more negative in their perception of the two e-learning programs we investigated.

Nevertheless, based on the findings of this study, it can be concluded that positive expectations about CEEs do not always match the actual perceptions of 
students. However, this is no reason to replace CEEs with traditional training methods with less attention for students' motivation and realistic competencies. That said, overall appreciation of students for authentic e-learning was found to be high. This study points to the limited understanding we have of how complex key variables of CEEs influence student behavior, and which are crucial for the implementation of authentic e-learning. Especially crucial in this regard is the variable "motivation." Although the definition of this concept is not unequivocal, recent research in evolutionary educational psychology seems to offer a good starting point (Bjorklund, 1997; Bjorklund \& Pellegrini, 2002; Heckhausen, 2000), as it offers a way to predict student motivation (Ryan \& Deci, 2000) or under what circumstances mechanisms such as specialization in a group allow room for feelings of competence, relatedness, and autonomy. These three factors are considered crucial for the development of intrinsic motivation, according to Ryan and Deci's influential Self Determination Theory (SDT). The distinction between intrinsic and extrinsic motivation in SDT is compelling, for intrinsic motivation may be of prime importance in authentic e-learning (as it leads to exploration, curiosity, and collaboration). Although not the direct aim of this study, it was found that the amount of intrinsic motivation reported by students and the amount of selfreported explorative behavior were highly correlated. This again illustrates the importance of the concept of intrinsic motivation in new learning environments based on constructivist principles. More research on these motivational processes in CEEs is necessary.

The main focus of this study was on students' perspectives, but there are many intervening variables involved, such as the role of the coach. Moreover, in this study individual differences between students were not taken into account. What works for one student may not work for another student. Although CEEs in distance education are often developed as "one size fits all," it is interesting to look for interaction effects of student characteristics, study outcomes, and appreciation of CEEs. In addition, the research presented in this article can be extended to other subject domains. All in all, a lot more research is needed to optimize implementations of competency based e-learning and authentic tasks in CEEs.

\section{Notes on Contributors}

Rob Martens is a full professor. He works at the Center for the Study of Education and Instruction at Leiden University in the Netherlands, and at the Educational Technology Expertise Center of the Open University of the Netherlands.

Theo Bastiaens is a full professor. He works at the Institut für Bildungswissenschaft und Medienforschung, at the Open University of Germany (FernUniversität Hagen) and at the Educational Technology Expertise Center of the Open University of the Netherlands.

Paul A. Kirschner is a full professor. He works at the Research Center Learning in Interaction at Utrecht University in the Netherlands, and at the Educational Technology Expertise Center of the Open University of the Netherlands. 


\section{References}

Bastiaens, Th., \& Martens, R. (2000). Conditions for web-based learning with real events. In B. Abbey (Ed.), Instructional and cognitive impacts of web-based education. Hershey, PA: The Idea Group.

Bitter, M., Sloep, P., \& Jansen, D. (2003). Learning to change: The Virtual Business Learning approach to professional workplace learning. Educational Technology and Society, 6, $18-25$.

Bjorklund, D. F. (1997). The role of immaturity in human development. Psychological Bulletin, $122,153-169$.

Bjorklund, D. F., \& Pellegrini, A. D. (2002). The origins of human nature: Evolutionary developmental psychology. Washington, DC: American Psychological Association.

Boekaerts, M., \& Minnaert, A. (in press). Assessment of students' feelings of autonomy, competence, and social relatedness: A new approach to measuring the quality of the learning process through self-assessment. In M. S. R. Segers, F. J. R. C. Dochy, \& E. C. Cascallar (Eds.), Optimizing new methods of assessment: In search of quality and standards. Dordrecht, the Netherlands: Kluwer Academic.

Broekkamp, H., van Hout-Wolters, B., Rijlaarsdam, G., \& van den Bergh, H. (2002). Importance in instructional text: Teachers' and students' perceptions of task demands. Fournal of Educational Psychology, 94, 260-272.

Brush, T. A. (1998). Embedding cooperative learning into the design of integrated learning systems: Rationale and guidelines. Educational Technology Research and Development, 46, 5-18.

Dalgarno, B. (1998). Choosing learner activities for specific learning outcomes: A tool for constructivist computer assisted learning design. In C. McBeath \& R. Atkinson (Eds.), Planning for progress, partnership and profit: Proceedings EdTech'98. Perth: Australian Society for Educational Technology.

Dillenbourg, P., Eurlings, A., \& Hakkarainen, K. (2001). European perspectives on computer supported learning. Maastricht, the Netherlands: Universiteit Maastricht.

Driscoll, M. P., Moallem, M., Dick, W., \& Kirby, J. E. (1994). How does the textbook contribute to learning in a middle school science class? Contemporary Educational Psychology, 19, 79-100.

EARLI. (2001). 9th European Conference for Research on Learning and Instruction: Abstracts. Fribourg, Switzerland: University of Fribourg.

Gagné, R., Briggs, L., \& Wager, W. (1992). Principles of instructional design (4th ed.). Fort Worth, TX: HBJ College Publishers.

Gros, B. (2001). Instructional design for computer-supported collaborative learning in primary and secondary education. Computers in Human Behavior, 17, 439-451.

Heckhausen, J. (2000). Evolutionary perspectives on human motivation. American Behavioral Scientist, 43, 1015-1029.

Herrington, J., \& Oliver, R. (2000). An instructional design framework for authentic learning environments. Educational Technology Research and Development, 48, $23-48$.

Howland, J. J., \& Moore, J. L. (2002). Student perceptions as distance learners in Internet-based courses. Distance Education, 23, 183-197.

Kaatinen, S., \& Kumpulainen, K. (2002). Collaborative inquiry and the construction of explanations in the learning of science. Learning and Instruction, 12, 189-212.

Kessels, J. (1999). A relational approach to curriculum design. In J. van den Akker, R. Branch, K. Gustafson, N. Nieveen, \& Tj. Plomp (Eds.), Design approaches and tools in education and training (pp. 59-71). Dordrecht, the Netherlands: Kluwer Academic.

Martens, R., Jochems, W., \& Kirschner, P. (Eds.). (2002). De didactiek van e-learning [The didactics of e-learning]. Verzameling papers gepresenteerd tijdens symposium op de Onderwijs Research Dagen in Antwerpen, 2002. Heerlen: Open Universiteit Nederland. 
Martens, R., Valcke, M., Poelmans, P., \& Daal, M. (1996). Functions, use and effects of embedded support devices in printed distance learning materials. Learning and Instruction, 6, 77-93.

Martens, R., Valcke, M., Portier, S., Weges, H., \& Poelmans, P. (1997). Research with interactive learning environments in three content domains: Descriptive statistics, continuous mathematics and substantive criminal law. Distance Education: An International fournal, 18, 44-58.

Martens, R. L. (1998). The use and effects of embedded support devices in independent learning. Ph.D. thesis, Uitgeverij Lemma BV, Utrecht, the Netherlands.

Naidu, S., \& Bernard, J. (1992). Enhancing academic performance in distance education with concept mapping and inserted questions. Distance Education: An International fournal, 13, $218-233$.

Pierce, J. W., \& Jones, B. F. (1998). Problem based learning: Learning and teaching in the context of problems. In Contextual teaching and learning: Preparing teachers to enhance student success in and beyond school (pp. 75-106). Columbus, OH: ERIC Clearinghouse.

Reiser, R. (2001). A history of instructional design and technology. Part 2: A history of instructional design. Educational Technology Research and Development, 49, 57-67.

Ryan, R. M., \& Deci, E. L. (2000). Self-determination theory and the facilitation of intrinsic motivation, social development, and well being. American Psychologist, 55, 68-78.

Simons, R.-J., van der Linden, J., \& Duffy, T. (2000). New learning. Dordrecht, the Netherlands: Kluwer Academic.

Sluijsmans, D. (2002). Student involvement in assessment. The training of peer assessment skills. Ph.D. thesis, Open Universiteit Nederland, Heerlen, the Netherlands.

Song, S. H., \& Keller, J. M. (2001). Effectiveness of motivationally adaptive computer-assisted instruction on the dynamic of motivation. Educational Technology Research and Development, 49, 5-22.

Stoof, A., Martens, R., van Merriënboer, J., \& Bastiaens, Th. (2002). The boundary approach of competence: A constructivist aid for understanding and using the concept of competence. Human Resource Development Review, 1, 345-365.

van Merriënboer, J. J. G., \& Martens, R. (2002). Computer-based tools for instructional design. Educational Technology, Research and Development, 50, 5-9.

Veerman, A. L. (2000). Computer-supported collaborative learning through argumentation [Ph.D. thesis]. Enschede, the Netherlands: Print Partners Ipskamp.

Vermetten, Y., Vermunt, J., \& Lodewijks, H. (2002). Powerful learning environments? How university students differ in their response to instructional measures. Learning and Instruction, $12,263-285$.

Wolters, C. A. (1998). Self-regulated learning and college students' regulation of motivation. Fournal of Educational Psychology, 90, 224-235.

Wöretshofer, J., \& Nadolski, R. (1998). Arrondissement Zomerweelde-een elektronische oefenrechtbank [Arrondissment Zomerweelde, an electronic training court]. Recht $\mathcal{E}$ Elektronische Media, 3, 20-21. 


\section{Appendix}

Table A1. Items of the scales on perception of the CEE

Scale titles (variable name Items per variable/scale in italic)

\begin{tabular}{|c|c|}
\hline $\begin{array}{l}\text { Perceived authenticity of the } \\
\text { e-learning environment }\end{array}$ & $\begin{array}{l}\text { - The tasks that I work at, resemble real-job tasks. } \\
\text { - I think the tasks are meaningful. } \\
\text { - What I learned, I can use in a professional context. } \\
\text { - What I learned can easily be transferred to real-job tasks. }\end{array}$ \\
\hline $\begin{array}{l}\text { Extent of confusion } \\
\text { regarding the e-learning } \\
\text { environment }\end{array}$ & $\begin{array}{l}\text { I find learning with these authentic tasks confusing. } \\
\text { - Authentic tasks cause a lot of confusion. } \\
\text { - An OU course book is less confusing than this environment. } \\
\text { - I'd rather learn in a more traditional way. }\end{array}$ \\
\hline $\begin{array}{l}\text { Experienced support in the } \\
\text { e-learning environment }\end{array}$ & $\begin{array}{l}\text { The learning environment adapts itself to my study speed. } \\
\text { - I can find the information I need in time. } \\
\text { - I get enough support in the learning environment. }\end{array}$ \\
\hline Extent of explorative & - I felt curious in the learning environment. \\
\hline behavior of the learner & $\begin{array}{l}\text { - I explored in the learning environment. } \\
\text { - My creativity was stimulated. }\end{array}$ \\
\hline $\begin{array}{l}\text { Extent of collaboration with } \\
\text { other learners }\end{array}$ & $\begin{array}{l}\text { I often work together with other students. } \\
\text { - I have learned from observing my fellow students. } \\
\text { The learning environment stimulates contacts with my fellow } \\
\text { students. }\end{array}$ \\
\hline $\begin{array}{l}\text { Positive opinion about the } \\
\text { use of role-play }\end{array}$ & $\begin{array}{l}\text { I enjoy the way the learning environment makes me work in a } \\
\text { role. } \\
\text { - My fellow students and I take different roles. } \\
\text { The working in roles stimulates active participation. }\end{array}$ \\
\hline $\begin{array}{l}\text { Opinion about usefulness of } \\
\text { discussion with other } \\
\text { learners }\end{array}$ & $\begin{array}{l}\text { The discussions with my fellow students are useful. } \\
\text { The discussion with my fellow students slowed down my study } \\
\text { pace. }(\mathrm{N}) \\
\text { The discussion with my fellow students contributed in a positive } \\
\text { way to my own learning. }\end{array}$ \\
\hline $\begin{array}{l}\text { Positive opinion about the } \\
\text { coach/facilitator }\end{array}$ & $\begin{array}{l}\text { The coach/facilitator was present in the learning environment. } \\
\text { - The coach/facilitator provides me with feedback. } \\
\text { - The coach/facilitator provides me with clues and tips. }\end{array}$ \\
\hline $\begin{array}{l}\text { The e-learning } \\
\text { environment urges } \\
\text { exploration }\end{array}$ & $\begin{array}{l}\text { The learning environment does not invite to explore things. (N) } \\
\text { - The learning environment stimulates solving problems. } \\
\text { - The learning environment stimulates discovery learning. }\end{array}$ \\
\hline The e-learning is innovative & $\begin{array}{l}\text { Learning in such a learning environment is new to me. } \\
\text { This learning environment is innovative. } \\
\text { Learning in such a learning environment is not different from } \\
\text { what I am used to. (N) }\end{array}$ \\
\hline Intrinsic motivation & $\begin{array}{l}\text { - I enjoyed learning in this environment. } \\
\text { - This learning environment is fun. } \\
\text { - I did not like this learning environment. (N) } \\
\text { - This activity did not hold my attention at all. (N) } \\
\text { - I would describe this activity as very interesting. }\end{array}$ \\
\hline
\end{tabular}

Note. $(\mathrm{N})=$ reversed item; all items are translated from Dutch. 